Indexed by

\title{
Scopus
}

\section{INVESTIGATING THE BEHAVIOR OF PILED RAFT FOUNDATION IN CORE WALL FOUNDATION OF HIGH-RISE BUILDINGS}

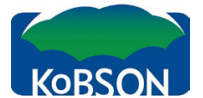

Soogle

\section{Tuan Nguyen Anh}

Ho Chi Minh City University of Transport, Faculty of Transportation Engineering, Ho Chi Minh City, Vietnam

\section{Vu Anh Nguyen Le}

Vasu Chartered Engineers, Ho

Chi Minh City, Vietnam
Tri Quoc Pham

Ho Chi Minh City University of Transport, Faculty of Civil Engineering, Ho Chi Minh City, Vietnam

Key words: piled raft foundation, FEM, soft soil, high-rise buildings, moment doi:10.5937/jaes0-30025

Cite article:

Anh Nguyen T., Le Nguyen Anh V., Pham Quoce T. (2021) INVESTIGATING THE BEHAVIOR OF PILED RAFT FOUNDATION IN CORE WALL FOUNDATION OF HIGH-RISE BUILDINGS, Journal of Applied Engineering Science, 19(4), 1056 - 1064, DOI:10.5937/ jaes0-30025 


\title{
INVESTIGATING THE BEHAVIOR OF PILED RAFT FOUNDATION IN CORE WALL FOUNDATION OF HIGH-RISE BUILDINGS
}

\author{
Tuan Nguyen Anh ${ }^{1 *}$, Vu Anh Nguyen Le ${ }^{2}$, Tri Quoc Pham ${ }^{3}$ \\ ${ }^{1}$ Ho Chi Minh City University of Transport, Faculty of Transportation Engineering, Ho Chi Minh City, \\ Vietnam \\ ${ }^{2}$ Vasu Chartered Engineers, Ho Chi Minh City, Vietnam \\ ${ }^{3}$ Ho Chi Minh City University of Transport, Faculty of Civil Engineering, Ho Chi Minh City, Vietnam
}

Core structure is an indispensable part of high buildings. Normally, the foundation of the core structure has a raft of larger size than the other foundations in the same project; therefore, the foundation of the core structure can be viewed as a small piled raft foundation. Currently, when calculating the piled foundation of the core, it is mostly assumed that the piles system will bear all the project loads. But this calculation method is not suitable for the actual constructions as well as does not make full use of the bearing capacity of the structure and the ground, leading to using more materials and causing more waste. Core structure aims to increase both stiffness and horizontal load capacity in high-rise buildings, so the moment inside the core transmitted to the foundation is very large. One of the shortcomings of the Plaxis 3D Foundation software is its inability to declare the moment affecting on the foundation due to the loads in this program just includes distributed loads, line loads and point loads in the geometry model. Consequently, when using Plaxis 3D Foundation software to calculate the core wall foundation of high-rise buildings, this moment is converted into an equivalent pair of moments. The research shows that when the core foundation of a high-rise building is placed on soft soil, the pile carries $96 \%$, most of the load transmitted to the foundation. However, when the foundation is placed on hard soil, the soil surrounding the raft will bear about $10 \%$ of the load transmitted to the foundation. If this matter is skipped, there will be a large error in calculation and design.

Key words: piled raft foundation, FEM, soft soil, high-rise buildings, moment

\section{INTRODUCTION}

Piled raft foundation is used widely in the structure of high-rise buildings because of its capability to bear load, and the piles and raft settlement are improved significantly compared to the conventional piled foundation. Baziar et al. showed the benefits of using piled raft foundation and application of piled raft foundation in hard clay [1]. In addition, there are some other examples about using piled raft foundation for different soil structures, which are found in Hemsley's books [2]. The efficiency of piled raft foundation is almost presented by Randolph, in which, they are rafts which can bear the above load themselves, and piles are added to increase the total loading capacity and make settlement, deformation between raft-piles in allowable limit [3]. Beckett, Bowels stated the same idea that the piles must be designed in such a way that most of their bearing capacity is utilized to transfer the loads from superstructures, through weak, compressible strata or water onto stronger, more compact, less compressible and stiffer soil or rock at depth $[4,5]$.

Poulos presented the strip on springs method to analyze the settlement of piled raft foundation [6]. Part of the raft is treated as a trip and the piles are treated as springs. This substitution was made for the four interactive components (raft-raft, pile-pile, raft-pile, pile-raft). The impact of external factors was analyzed and calculated by computer in order to define the soil settlement of each part.
These numbers on settlement and the series were then analyzed in order to identify the settlement, the moment due to the load impacted on the series and the settlement of the soil outside the series of the raft.

This method was performed via a computer program called GASP (Geotechnical Analysis of Strip with Piles) and it demonstrated that the settlement was similar to the previous analysis methods. However, this method has some limitations, especially it does not consider the torque in raft and the settlement at a point where the two series intersect the point of analysis.

Poulos used the differential finite method called plate on springs. This analysis was done via GARP program [7]. This program allows users to classify the geological cross section and the effect of the pile on the final load capacity for both compressive and tensile cases, to develop the slip resistance under the raft and to demonstrate soil settlement area in the foundation system. This approximate method is similar to how the GASP program works for piles range.

A later version of GARP replaced the differential finite method for rafts with a finite element method (FEM) and used an innovative approach to develop limited load capacity in piles.

$[20,25]$ described a similar approach, in which different interactions are obtained from elastic theory and nonlin- 
ear behavior of the piles is considered through the hypothesis of the hyperbolic curve of the load - settlement of the single pile. The pile-pile interaction applies only to elastic components of pile settlement, while the nonlinear pile settlement component is calculated from the load inside the pile $[8,9]$.

The finite element method (FEM) combined with boundary elements was developed by Hain and Lee [10]. This method considers finite elements for rafts and boundary elements for pile groups. In this method, the elastic method in the continuous environment Mindlin is used to solve the interaction of the piles. The method of Hain and Lee has the advantage of using the model's symmetrical quarter angle so that it can be used to analyze the piled raft foundation of more than 200 piles. It also allows changes in geometry, pile hardness and raft thickness. As a result, the FEM method is more effective than the previous method for analyzing the piled raft foundation.

The 2D numerical analysis method has been examined by Desai, Hewitt and Gue (1994), Prakoso and Kulhawy (2001), Seo (2006) [11-14]. In these analyses, FLAC software is used to model piled raft foundations. The foundations are modeled as plain strain or axial symmetry. In both cases, an approximate calculation is made, especially for the pile, so that the soil settlement and raft size can be determined. However, being similar to spring-based plate analysis, this analysis still fails to determine torque in rafts.

Many authors have performed 3-dimensional FEM for piled raft foundation system to study the behavior of load - settlement, the interaction between the rafts and piles with surrounding ground as well as study the load-bearing capacity of raft and pile group in piled raft foundation structure [15-21]. But although many such investigations were conducted with remarkable success, the limitations of this traditional approach cannot be disregards and maybe are unacceptable in modern practice [4]. Furthermore, there was little change in the number of researches on the effect of piled raft foundation design on highrise building considering soil - pile - structure interaction. This paper applies the finite element method (FEM) using Plaxis 3D Foundation software [15] to study the behavior of piled raft foundation in the core wall foundation of high-rise buildings. Authors also compare the total applied load on piles when being calculated by Safe and Plaxis 3D Foundation. As a results, the load distribution on piled raft foundation of high-rise buildings placed on soft soil and hard soil is determined.

\section{MATERIALS AND METHODS}

\section{Plaxis 3D Foundation}

The Plaxis 3D Foundation program is a three-dimensional finite element program, developed by Plaxis, a company located in the Netherlands. It is used to analyze the deformation and stability for foundation structures, including off-shore foundations [22]. The Plaxis 3D interface compose two sub-programs as Input and Output. At
Input, by setting material data sets, properties of soil and other elements (boreholes, embedded piles, plates, etc.) are assigned. The basic soil elements of the 3D finite element mesh are the 10-node tetrahedral elements [23].

\section{Applications of Plaxis 3D Foundation in core wall foundation design}

\section{Parameters}

The piled foundation has a scaffold size of $2.1^{*} 2.1 \mathrm{~m}, 1 \mathrm{~m}$ thick, placed on four $9 \mathrm{~m}$-long $300 \times 300 \mathrm{~mm}$ piles of reinforced concrete with load $P=1000 \mathrm{kN}$ and moment $M=100 \mathrm{kN} . \mathrm{m}$.

Soil parameters are summarized in Table 1.

Table 1: Summary of soil parameters

\begin{tabular}{|c|c|c|c|}
\hline Parameters & Unit & Layer 1 & Layer 2 \\
\hline Thickness & $\mathrm{m}$ & 4.5 & 15 \\
\hline Unit weight yunsat & $\mathrm{kN} / \mathrm{m}^{3}$ & 16 & 20 \\
\hline $\begin{array}{c}\text { Saturated unit weight } \\
\text { ysat }\end{array}$ & $\mathrm{kN} / \mathrm{m}^{3}$ & 16.7 & 20.3 \\
\hline Young's modulus $\mathrm{E}$ & $\mathrm{kN} / \mathrm{m}^{2}$ & 500 & 13000 \\
\hline Poisson ratio v & - & 0.35 & 0.3 \\
\hline Cohesion c & $\mathrm{kN} / \mathrm{m}^{2}$ & 1 & 1 \\
\hline Internal friction angle $\varphi$ & degree & 8 & 31 \\
\hline Dilation angle $\Psi$ & degree & 0 & 1 \\
\hline
\end{tabular}

The plan and section views are shown in Fig. 1, which the length unit is ' $m m$ '.

\section{Calculate the applied load on the top of the pile by analytical method}

Weight of the raft:

$\mathrm{W}_{\text {raft }}=2.1 * 2 \cdot 1 * 1.0 * 25=110.25 \mathrm{kN}$

$\mathrm{N}^{\mathrm{tt}(\text { raft })}=\mathrm{N}^{\mathrm{tt}}+\mathrm{W}_{\text {raft }}=1000+110.25=1110.25 \mathrm{kN}$

Where the unit weight of concrete equal $25 \mathrm{kN} / \mathrm{m}^{3}$

Applied load on the top of the pile:

$P_{1,2}=\frac{N^{t t(\text { raft })}}{n_{\text {pile }}}-\frac{M^{t t}}{\sum x_{i}^{2}} x_{\max }=\frac{1110.25}{4}-\frac{100}{4^{\star} 75^{2}} 0.75=245 \mathrm{kN}$

$P_{3,4}=\frac{N^{t t(\text { raft })}}{n_{\text {pile }}}-\frac{M^{t t}}{\sum x_{i}^{2}} x_{\max }=\frac{1110.25}{4}-\frac{100}{4^{*} 75^{2}} 0.75=311 \mathrm{kN}$

Calculate the applied load on the top of the pile using Plaxis 3D Foundation software [22]

Concentrated force is referred to as an evenly distributed force acting on the foundation.

$q=N^{t t} /\left(L^{*} B\right)=1000 /(2.1 * 2.1)=227 \mathrm{kN} / \mathrm{m}^{2}$

The load impact on the foundation without a moment is shown in Fig. 2.

Moment is converted into two random pair of moments $F$ as shown in Fig. 3.

$M=2^{*} F^{*}(L / 2) \rightarrow F=M / L=100 / 1.05=95 \mathrm{kN}$

Force $F$ is converted into the force which is evenly dis- 


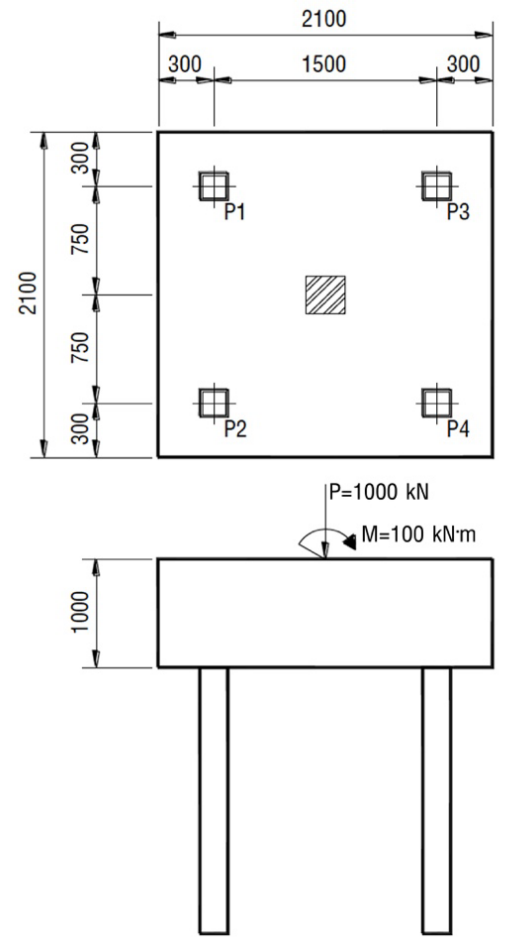

Figure 1: The plan and section views of the piled raft foundation

$\mathrm{q}=227 \mathrm{kN} / \mathrm{m}^{2}$

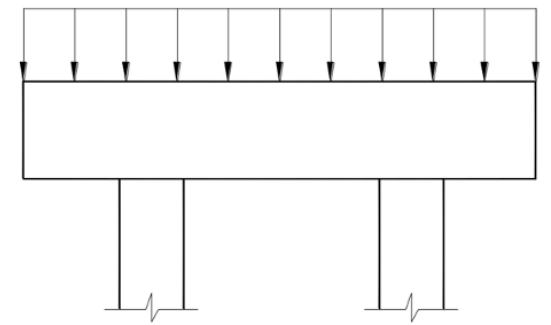

Figure 2: Load impact on the foundation without moment

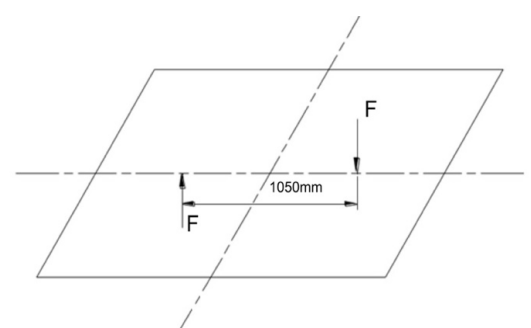

Figure 3: Moment is converted into two random pairs of moments

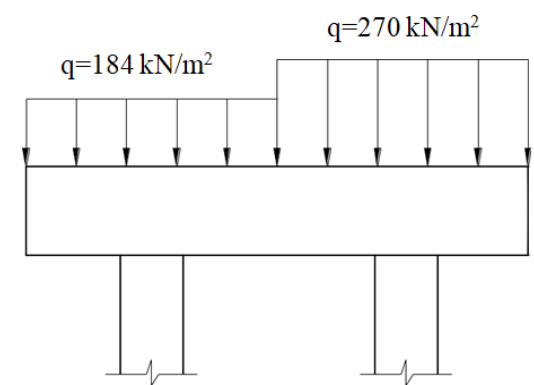

Figure 4: Diagram of load calculation in FEM when moment is counted

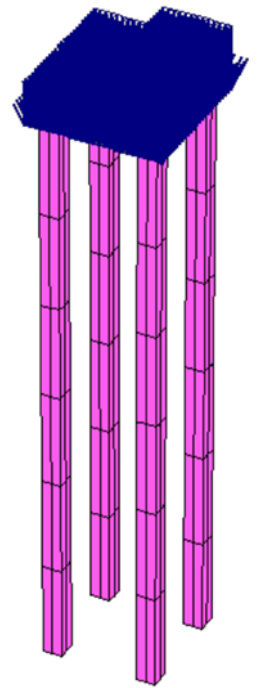

(a)

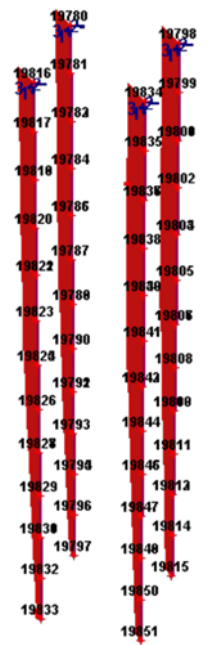

(b)
Figure 5: Calculation model and results by Plaxis tributed in half of the foundation area.

$\mathrm{q}_{2}=\mathrm{F} /\left(0.5 \mathrm{~F}_{\text {foundation }}\right)=95 /\left(0.5^{\star} 2.1^{*} 2.1\right)=43 \mathrm{kN} / \mathrm{m}^{2}$

The applied load to the foundation when moment is counted in the Plaxis 3D Foundation software is shown in Fig.4.

Calculation model and results obtained from Plaxis 3D Foundation software are shown in Fig. 5(a,b).

In the model, three distinct elements are illustrated such as embedded piles for the piles, floor element for the raft and volume element for the soil. At the bottom of the model and in the two horizontal directions, the boundary is fullly rigid.

Results calculated by Plaxis are summarized in Table 2 .

Comparison of two results obtained from analytical method and Plaxis 3D Foundation

Results calculated by analytical method and Plaxis are different and the difference is $7.2 \%$ for piles $\mathrm{P} 1, \mathrm{P} 2$ and $8 \%$ for piles $\mathrm{P} 3, \mathrm{P} 4$, respectively (Table 3 ). This differ-

Table 2: Load impact calculation result by Plaxis

\begin{tabular}{|c|c|}
\hline Pile & Load pile (kN) \\
\hline P1 & 264 \\
\hline P2 & 264 \\
\hline P3 & 286 \\
\hline P4 & 286 \\
\hline
\end{tabular}

Table 3: Compare results obtained from analytical method and Plaxis

\begin{tabular}{|c|c|c|c|}
\hline Pile & $\begin{array}{c}\text { Analytical method } \\
(\mathbf{k N})\end{array}$ & $\begin{array}{c}\text { Plaxis } \\
(\mathbf{k N})\end{array}$ & $\begin{array}{c}\text { Difference } \\
(\mathbf{\%})\end{array}$ \\
\hline P1 & 245 & 264 & 7.2 \\
\hline P2 & 245 & 264 & 7.2 \\
\hline P3 & 311 & 286 & 8.0 \\
\hline P4 & 311 & 286 & 8.0 \\
\hline
\end{tabular}


Table 4: Summary of soil parameters for Ly Chinh Thang project

\begin{tabular}{|c|c|c|c|c|c|c|c|c|c|}
\hline & \multicolumn{8}{|c|}{ Materials } & \multirow[b]{2}{*}{ Unit } \\
\hline & $\begin{array}{c}\text { Layer } 1 \\
\text { Sandy } \\
\text { Clay }\end{array}$ & $\begin{array}{c}\text { Layer } 2 \\
\text { Sandy } \\
\text { Clay }\end{array}$ & $\begin{array}{c}\text { Layer } 3 \\
\text { Clayey } \\
\text { sand }\end{array}$ & $\begin{array}{c}\text { Layer } 4 \\
\text { Sandy } \\
\text { Clay }\end{array}$ & $\begin{array}{c}\text { Layer } 5 \\
\text { Clayey } \\
\text { sand }\end{array}$ & $\begin{array}{l}\text { Layer } 6 \\
\text { Hard clay }\end{array}$ & $\begin{array}{c}\text { Layer } 7 \\
\text { Clayey } \\
\text { sand }\end{array}$ & Concrete & \\
\hline Model & $\mathrm{M}-\mathrm{C}$ & $\mathrm{M}-\mathrm{C}$ & $\mathrm{M}-\mathrm{C}$ & $M-C$ & $M-C$ & $\mathrm{M}-\mathrm{C}$ & $M-C$ & Elastic & - \\
\hline Type & Undrained & Undrained & Drained & Drained & Undrained & Undrained & Drained & Nonporous & - \\
\hline yunsat & 20 & 19.9 & 20.1 & 18.3 & 19.9 & 20.4 & 20.4 & 25 & $\mathrm{kN} / \mathrm{m}^{3}$ \\
\hline ysat & 20 & 19.9 & 20.1 & 18.3 & 19.9 & 20.4 & 20.4 & - & $\mathrm{kN} / \mathrm{m}^{3}$ \\
\hline$E$ & 18180 & 19530 & 30000 & 10560 & 23560 & 26500 & 29950 & $3 E+07$ & $\mathrm{kN} / \mathrm{m}^{2}$ \\
\hline $\mathrm{v}$ & 0.3 & 0.3 & 0.3 & 0.3 & 0.3 & 0.3 & 0.3 & 0.15 & - \\
\hline $\mathrm{C}$ & 30.7 & 19.8 & 5.9 & 19.9 & 5.8 & 38.2 & 5.2 & - & $\mathrm{kN} / \mathrm{m}^{2}$ \\
\hline$\varphi$ & 13.5 & 11.5 & 22.4 & 9.9 & 23.6 & 16 & 24.6 & - & degree \\
\hline$\Psi$ & 0 & 0 & 0 & 0 & 0 & 0 & 0 & - & degree \\
\hline $\mathrm{k}_{\mathrm{v}}=\mathrm{k}_{\mathrm{h}}$ & $5.2 e^{-5}$ & $6.7 e^{-3}$ & $4 . e^{-2}$ & $7.1 e^{-3}$ & 8.6 & $6.5 e^{-7}$ & 0.76 & - & m/day \\
\hline Rinter & 0.7 & 0.7 & 0.8 & 0.7 & 0.8 & 0.8 & 0.7 & - & - \\
\hline Thickness & 6.5 & 3.0 & 15.5 & 3.7 & 7.0 & 20 & 14.3 & - & $\mathrm{m}$ \\
\hline
\end{tabular}

ence is resulted from the fact that the analytical method does not consider the influence of ground surrounding the foundation and piles.

\section{CALCULATION SIMULATION OF REAL CONSTRUCTIONS}

\section{Office Building Ly Chinh Thang, Vietnam}

\section{Calculation parameters}

The piled raft has the dimension of $8.2^{*} 22.6^{*} 2.5 \mathrm{~m}$ and is located in the soil layer No.3. The used piles are barrette piles with the size of $1000^{*} 2800 \mathrm{~mm}$, length $48 \mathrm{~m}$ and the end of the pile is plugged into the soil layer No. 7 .

Soil parameters are summarized in Table 4.

The groundwater level is at $-4.5 \mathrm{~m}$ and the bottom of the raft is at $-17.35 \mathrm{~m}$.

The constitutive model used in Plaxis is a linear elastic plastic model with a Mohr-Coulomb (M-C) plasticity criterion.

In which, $\mathrm{k}_{\mathrm{v}}$ and $\mathrm{k}_{\mathrm{h}}$ are vertical permeability and horizontal permeability respectively.

From the Extended 3D Analysis of Building Systems (ETABS) model results calculated by authors, the three most dangerous internal force pairs to calculate the core wall foundation are shown in Table 5 [24].

Table 5: Three most dangerous internal force pairs to calculate the core wall foundation

\begin{tabular}{|c|c|c|c|}
\hline Parameters & $\begin{array}{c}\text { Maximum } \\
\text { vertical force } \\
\mathbf{N}_{\max }(\mathbf{k N})\end{array}$ & $\begin{array}{c}\text { Moment } \mathbf{M}_{\text {2res }} \\
\mathbf{( k N . m )}\end{array}$ & $\begin{array}{c}\text { Moment } \\
\mathbf{M}_{\text {3res }} \\
(\mathbf{k N} . \mathbf{m})\end{array}$ \\
\hline $1^{\text {st }}$ pair & 181287 & 37645 & -10329 \\
\hline $2^{\text {nd }}$ pair & 174837 & 25818 & 150578 \\
\hline $3^{\text {rd }}$ pair & 165339 & -3670 & 147672 \\
\hline
\end{tabular}

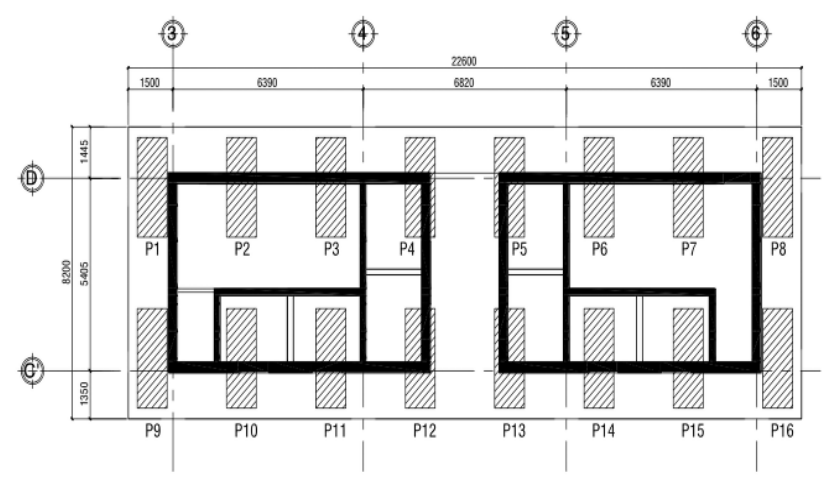

Figure 6: The layout of core wall foundation at Ly Chinh Thang project

The layout of the building's core wall foundation is illustrated in Fig. 6, which the unit of length is ' $\mathrm{mm}$ '.

\section{Calculation model in Plaxis 3D Foundation}

The Plaxis 3D Foundation calculation model for the core wall foundation of the project is shown in Figs. 7 and 8.

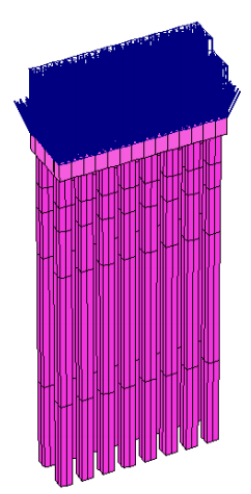

(a)

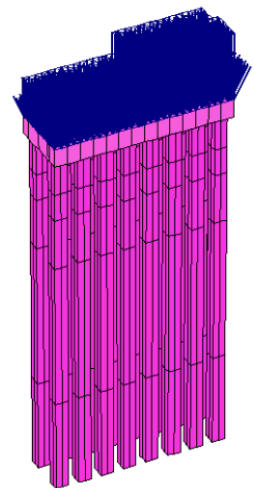

(b)

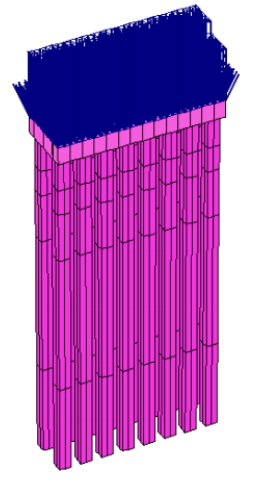

(c)
Figure 7: Plaxis 3D calculation models 


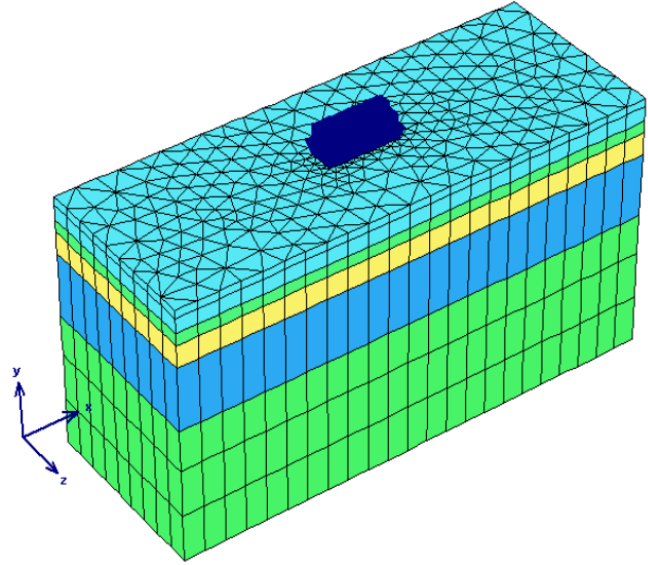

Figure 8: Layout of the calculation model in Plaxis 3D Calculation results

The calculation results of the core wall foundation of Ly Chinh Thang project by Plaxis 3D Foundation software are summarized in Table 6.

Table 6: Calculation results of the core wall foundation from Plaxis

\begin{tabular}{|c|c|c|c|}
\hline \multirow{2}{*}{ Pile } & \multicolumn{3}{|c|}{ Load pile (kN) } \\
\cline { 2 - 4 } & Case 1 & Case 2 & Case 3 \\
\hline P1 & 14405.5 & 9703.6 & 9692 \\
\hline P2 & 9647.8 & 6833.4 & 5980.4 \\
\hline P3 & 8858.8 & 6708.5 & 5341.4 \\
\hline P4 & 8688.5 & 7021.9 & 5233.0 \\
\hline P5 & 8640.9 & 7492.5 & 5190.0 \\
\hline P6 & 8794.8 & 8035 & 5293.3 \\
\hline P7 & 9683.2 & 9301.2 & 6008.7 \\
\hline P8 & 14421 & 14451 & 9705.3 \\
\hline P9 & 15533 & 10537 & 14871 \\
\hline P10 & 10674.8 & 7569.1 & 10522.6 \\
\hline P11 & 9916.6 & 7428.3 & 9904.6 \\
\hline P12 & 9673.5 & 7772.2 & 9704.6 \\
\hline P13 & 9751.7 & 8140.2 & 9766.9 \\
\hline P14 & 9850.7 & 8747.7 & 9848.3 \\
\hline P15 & 10771.1 & 9987.1 & 10612.3 \\
\hline P16 & 15529 & 15212.8 & 14869 \\
\hline
\end{tabular}

Load distribution coefficient in case 1:

$\alpha_{p r 1}=\sum R_{p i} / R_{\text {total }}=174840 / 193280=0.9046$

Thus, the percentage of the applied load to the pile is $90.46 \%$.

Load distribution coefficient in case 2 :

$a_{\mathrm{pr} 2}=\Sigma R_{\mathrm{pi}} / R_{\text {total }}=144941 / 163571=0.8916$

Thus, the percentage of the applied load to the pile is $89.16 \%$.

Load distribution coefficient in case 3:

$\alpha_{\mathrm{pr} 3}=\sum \mathrm{R}_{\mathrm{pi}} / \mathrm{R}_{\text {total }}=142543 / 159665=0.8928$
Thus, the percentage of the applied load to the pile is $89.28 \%$.

Where $R_{\text {total }}$ obtained from ETABS software.

Results calculated by Safe software for the core wall foundation of Ly Chinh Thang project

Safe software developed by Computers and Structures, INC. (CSI) is the ultimate tool for designing concrete floor and foundation systems. The calculation model by SAFE is shown in Fig. 9 [24].

The calculation results of the applied load on the pile by Safe software are summarized in table 7 .

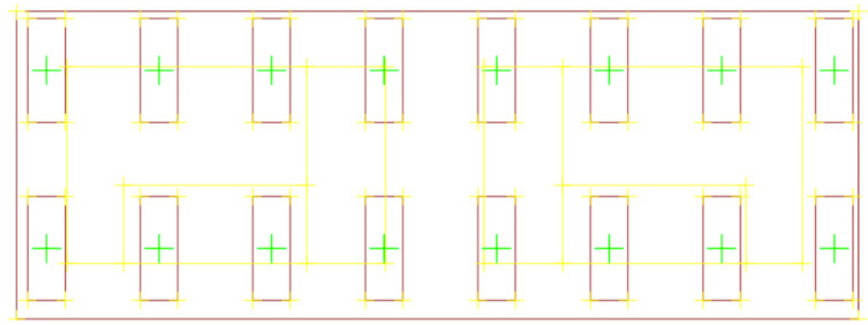

Figure 9: Calculation model of core wall foundation by Safe

Table 7: Calculation results of core wall foundation by Safe

\begin{tabular}{|c|c|c|c|}
\hline \multirow{2}{*}{ Pile } & \multicolumn{3}{|c|}{ Load pile (kN) } \\
\cline { 2 - 4 } & Case 1 & Case 2 & Case 3 \\
\hline P1 & 12667 & 4427 & 4201 \\
\hline P2 & 12677 & 6251 & 4646 \\
\hline P3 & 13140 & 7947 & 5001 \\
\hline P4 & 13558 & 9082 & 5123 \\
\hline P5 & 13335 & 9440 & 5019 \\
\hline P6 & 12103 & 9496 & 4704 \\
\hline P7 & 10382 & 9661 & 4126 \\
\hline P8 & 8688 & 10143 & 3287 \\
\hline P9 & 13148 & 7873 & 14617 \\
\hline P10 & 13253 & 9898 & 15342 \\
\hline P11 & 13291 & 11607 & 15972 \\
\hline P12 & 13251 & 12773 & 16439 \\
\hline P13 & 12867 & 13235 & 16485 \\
\hline P14 & 11805 & 13494 & 16007 \\
\hline P15 & 10235 & 13861 & 15319 \\
\hline P16 & 8352 & 14194 & 14185 \\
\hline
\end{tabular}

Case 2 is chosen to make the comparison between Plaxis 3D Foundation and Safe. Results are shown in Figs.10, 11.

\section{Sacomreal Apartment - Hung Vuong, Vietnam}

\section{Calculation parameters}

The pile raft has dimensions of $16.6^{*} 10.6^{*} 2.3 \mathrm{~m}$ and is located in the soil layer 1a. The used pile is a bored pile 
Table 8: Summary of soil parameter at Sacomreal-Hung Vuong

\begin{tabular}{|c|c|c|c|c|c|c|c|c|c|}
\hline & \multicolumn{8}{|c|}{ Materials } & \multirow[b]{2}{*}{ Unit } \\
\hline & $\begin{array}{c}\text { Layer } \\
\text { 1a Weak } \\
\text { Clay }\end{array}$ & $\begin{array}{c}\text { Layer } 2 \\
\text { Sandy } \\
\text { Clay }\end{array}$ & $\begin{array}{c}\text { Layer } 3 \\
\text { Clayey } \\
\text { Sand }\end{array}$ & $\begin{array}{c}\text { Layer } 4 a \\
\text { Clay }\end{array}$ & $\begin{array}{c}\text { Layer 5a } \\
\text { Clayey } \\
\text { Sand }\end{array}$ & $\begin{array}{c}\text { Layer } 5 b \\
\text { Sand }\end{array}$ & $\begin{array}{c}\text { Layer } 6 \\
\text { Clay }\end{array}$ & $\begin{array}{c}\text { Layer } 7 \\
\text { Sand }\end{array}$ & \\
\hline Model & $M-C$ & $M-C$ & $M-C$ & $M-C$ & $M-C$ & $M-C$ & $M-C$ & $M-C$ & - \\
\hline Type & Undrained & Undrained & Undrained & Undrained & Undrained & Undrained & Drained & Drained & - \\
\hline yunsat & 15.2 & 18.2 & 19.1 & 18.27 & 19.3 & 19.2 & 18.1 & 19.92 & $\mathrm{kN} / \mathrm{m}^{3}$ \\
\hline ysat & 15.2 & 18.2 & 19.1 & 18.27 & 19.3 & 19.2 & 18.1 & 19.92 & $\mathrm{kN} / \mathrm{m}^{3}$ \\
\hline$E$ & 1460 & 9700 & 17395 & 12375 & 21140 & 25235 & 13200 & 35120 & $\mathrm{kN} / \mathrm{m}^{2}$ \\
\hline $\mathrm{v}$ & 0.25 & 0.3 & 0.3 & 0.3 & 0.3 & 0.3 & 0.3 & 0.3 & - \\
\hline$c$ & 7.9 & 14.25 & 8.1 & 33.75 & 8.9 & 5.22 & 35.24 & 5.82 & $\mathrm{kN} / \mathrm{m}^{2}$ \\
\hline$\varphi$ & 3.4 & 15.3 & 22.9 & 14.9 & 24.4 & 34 & 15.6 & 34.4 & degree \\
\hline$\psi$ & 0 & 0 & 0 & 0 & 0 & 0 & 0 & 4.4 & degree \\
\hline $\mathrm{k}_{\mathrm{v}}=\mathrm{k}_{\mathrm{h}}$ & 10.2 & $7.4 \mathrm{e}^{-3}$ & 0.12 & $7.5 e^{-5}$ & 0.24 & 86.4 & $4.5 e^{-7}$ & 86.4 & $\mathrm{~m} /$ day \\
\hline Rinter & 0.7 & 0.7 & 0.8 & 0.7 & 0.8 & 0.8 & 0.7 & 0.8 & - \\
\hline Thickness & 7.0 & 2.8 & 5.4 & 11 & 16.9 & 15.1 & 12.8 & - & $\mathrm{m}$ \\
\hline
\end{tabular}

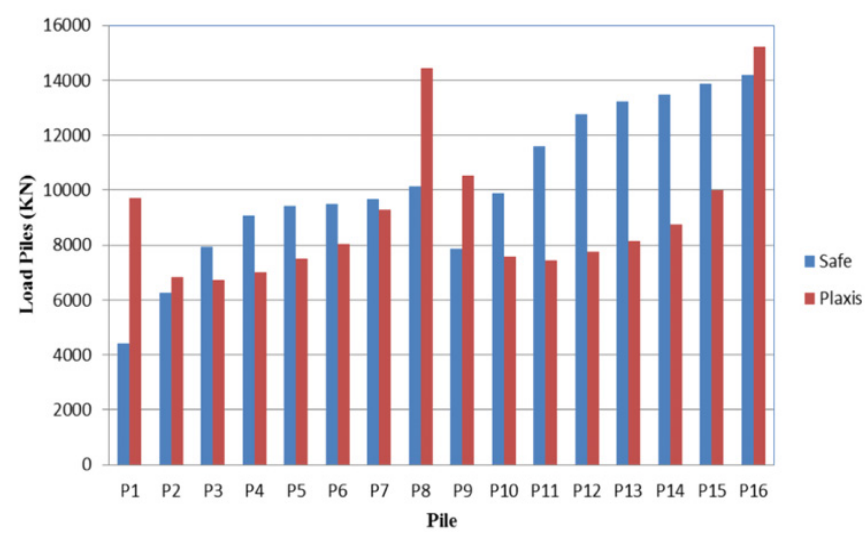

Figure 10: Comparison of applied load on piles between Plaxis and Safe

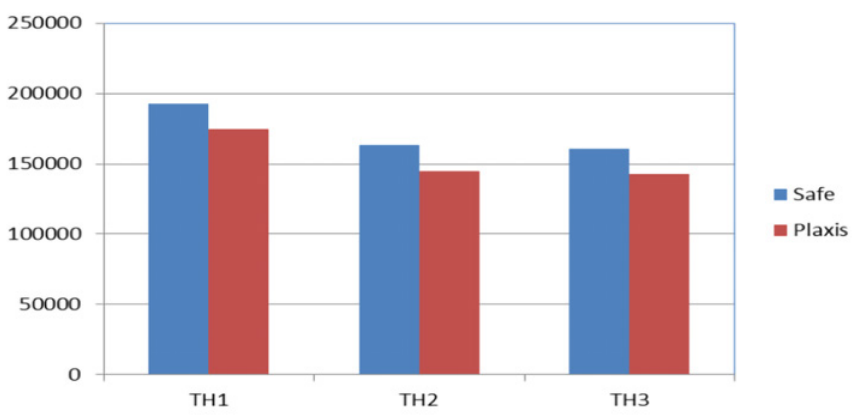

Figure 11: Comparison of Total applied load on piles between Plaxis and Safe

with diameter $D=1 \mathrm{~m}$, length $52 \mathrm{~m}$ and the tip of the pile is plugged into soil layer 7 .

Based on the geological survey profile, the parameters of the ground soil are shown in Table 8.

The groundwater level is at the elevation of $-0.4 \mathrm{~m}$ and the base of the raft is at $-6.3 \mathrm{~m}$.
Table 9 summarizes the most dangerous internal force pairs to calculate the foundation for core wall.

Fig.12 shows the core wall foundation plan of the project which, unit for measuring length is ' $\mathrm{mm}$ '.

Table 9: The three most dangerous pairs of internal forces to calculate core wall foundations

\begin{tabular}{|c|c|c|c|}
\hline Parameters & $\begin{array}{c}\text { Maximum } \\
\text { vertical force } \\
\mathbf{N}_{\text {max }}(\mathbf{k N})\end{array}$ & $\begin{array}{c}\text { Moment } \mathbf{M}_{\text {2res }} \\
(\mathbf{k N . m})\end{array}$ & $\begin{array}{c}\text { Moment } \\
\mathbf{M}_{\text {3res }} \\
(\mathbf{k N . m})\end{array}$ \\
\hline $1^{\text {st }}$ pair & 107020 & 32057 & -1077 \\
\hline $2^{\text {nd }}$ pair & -118191 & 5464 & 91566 \\
\hline $3^{\text {rd }}$ pair & 32676 & -648 & 94903 \\
\hline
\end{tabular}

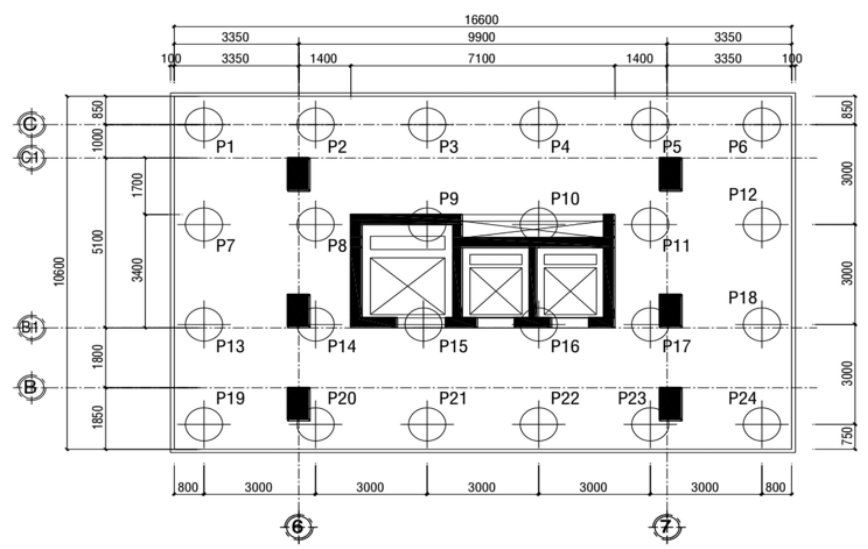

Figure 12: Layout of Core wall foundation of Sacomreal-Hung Vuong

Calculation model in Plaxis 3D Foundation

Fig.s 13, 14 show the numerical model for core wall foundation of the project. 


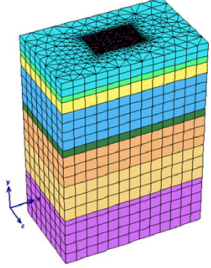

Figure 13: Calculation model plan in Plaxis 3D

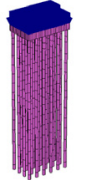

(a)

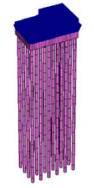

(b)

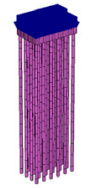

(c)
Figure 14: Calculation model in Plaxis 3D

\section{Calculation results}

Table 10 shows the calculation results of core wall foundations of Sacomreal - Hung Vuong project by Plaxis 3D Foundation. Load distribution coefficient in case 3 :

$\alpha_{p r}=\Sigma R_{p i} /$ Rtotal $=112626 / 117137=0.9615$

Table 10: Calculation results of core wall foundation by Plaxis

\begin{tabular}{|c|c|c|c|}
\hline \multirow{2}{*}{ Pile } & \multicolumn{3}{|c|}{ Load pile (kN) } \\
\hline & Case 1 & Case 2 & Case 3 \\
\hline $\mathrm{P} 1$ & 6381.52 & 4380.92 & 5683.73 \\
\hline $\mathrm{P} 2$ & 4773.46 & 3763.25 & 4231.55 \\
\hline P3 & 4373.72 & 3897.77 & 3869.97 \\
\hline P4 & 4368.34 & 4346.30 & 3865.09 \\
\hline P5 & 4770.30 & 5203.60 & 4228.57 \\
\hline P6 & 6382.29 & 7483.74 & 5684.64 \\
\hline P7 & 5263.03 & 3328.75 & 4716.40 \\
\hline P8 & 3285.63 & 2396.93 & 2925.16 \\
\hline P9 & 2864.49 & 2390.22 & 2546.06 \\
\hline P10 & 2881.97 & 2714.90 & 2561.75 \\
\hline P11 & 3301.55 & 3454.52 & 2938.99 \\
\hline P12 & 5259.32 & 6013.57 & 4712.64 \\
\hline P13 & 5417.79 & 3278.92 & 4892.28 \\
\hline P14 & 3461.72 & 2391.03 & 3109.34 \\
\hline P15 & 3019.52 & 2376.80 & 2710.01 \\
\hline P16 & 3021.07 & 2683.98 & 2711.50 \\
\hline P17 & 3454.06 & 3424.13 & 3102.92 \\
\hline P18 & 5409.11 & 5928.37 & 4885.03 \\
\hline P19 & 7073.35 & 4259.04 & 6440.23 \\
\hline P20 & 5398.20 & 3654.97 & 4910.29 \\
\hline P21 & 4994.81 & 3791.95 & 4542.00 \\
\hline $\mathrm{P} 22$ & 5005.05 & 4247.47 & 4552.05 \\
\hline P23 & 5402.26 & 5070.74 & 4913.94 \\
\hline P24 & 7063.52 & 7304.39 & 6431.98 \\
\hline
\end{tabular}

Thus, the percentage of the applied load to the pile is $96.15 \%$.

Calculation results of core wall foundations of Sacomreal - Hung Vuong project by Safe

Fig. 15 shows the calculation model by Safe.

Table 11 presents the calculation results of load pile by Safe. Case 2 is chosen to make the comparison between Plaxis 3D Foundation and Safe. Results are shown in Figs. 16, 17.

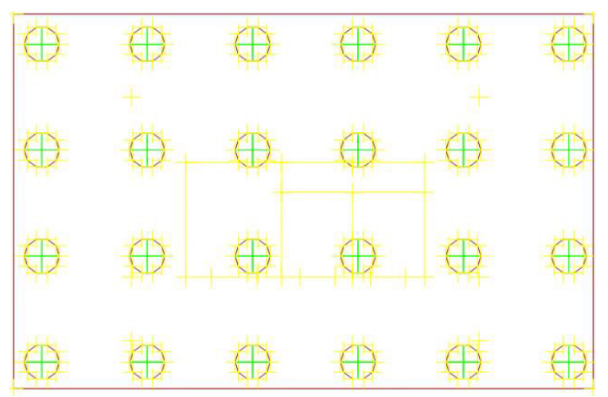

Figure 15: Calculation model by Safe for core wall foundation of Sacomreal - Hung Vuong project

Table 11: Calculation results of core wall foundation by Safe

\begin{tabular}{|c|c|c|c|}
\hline \multirow{2}{*}{ Pile } & \multicolumn{3}{|c|}{ Load pile (kN) } \\
\cline { 2 - 4 } & Case 1 & Case 2 & Case 3 \\
\hline P1 & 2939 & 1368 & 2757 \\
\hline P2 & 4314 & 1583 & 4014 \\
\hline P3 & 5094 & 3158 & 4733 \\
\hline P4 & 5117 & 4314 & 4756 \\
\hline P5 & 4366 & 4627 & 4064 \\
\hline P6 & 3000 & 4099 & 2815 \\
\hline P7 & 3700 & 577 & 3356 \\
\hline P8 & 5212 & 2441 & 4734 \\
\hline P9 & 6122 & 4296 & 5572 \\
\hline P10 & 6181 & 5736 & 5628 \\
\hline P11 & 5318 & 6105 & 4837 \\
\hline P12 & 3810 & 5448 & 3464 \\
\hline P13 & 4002 & 1118 & 3531 \\
\hline P14 & 5509 & 3069 & 4892 \\
\hline P15 & 6387 & 5019 & 5696 \\
\hline P16 & 6456 & 6565 & 5763 \\
\hline P17 & 5637 & 7017 & 5018 \\
\hline P18 & 4132 & 6328 & 3659 \\
\hline P19 & 3910 & 1548 & 3339 \\
\hline P20 & 5322 & 3505 & 4606 \\
\hline P21 & 6032 & 5309 & 5260 \\
\hline P22 & 6077 & 6782 & 5305 \\
\hline P23 & 5422 & 7362 & 4705 \\
\hline P24 & 4024 & 6747 & 3452 \\
\hline & & & \\
\hline & & 569 \\
\hline
\end{tabular}




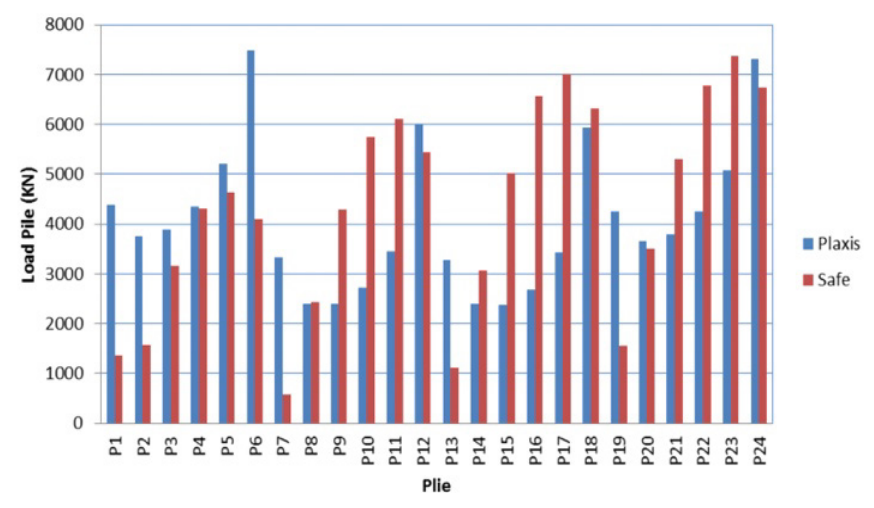

Figure 16: Comparison of applied load on piles between Plaxis and Safe

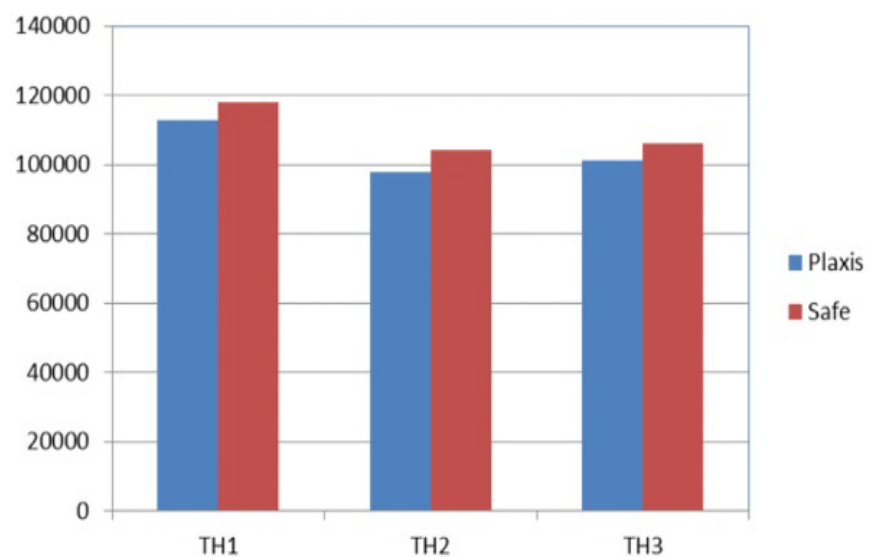

Figure 17: Comparison of total applied load on piles between Plaxis and Safe

\section{DISCUSSION}

It can be easily found that the load distribution coefficient in the 3 load cases of the two above calculation projects is almost unchanged.

In the apartment - office building Sacomreal - Hung Vuong, the raft foundation is placed on soft soil (silty clay) with $E=1,460 \mathrm{kN} / \mathrm{m}^{2}$. Looking at the table 10 , we can see that the load distribution coefficient apr is approximately equal to $96 \%$. It means that the piles carry the majority of the load and the raft does not have considerable effect. This result stays the same idea with the conventional design approach for the piled raft foundations presented by Randolph (1994) [3].

Ly Chinh Thang office building project is located on a hard soil layer with $E=30,000 \mathrm{kN} / \mathrm{m}^{2}$. The load distribution coefficient apr is approximately $90 \%$. This means that the soil around the raft shares partly a portion of about $10 \%$ of the total load transmitted to the foundation. It is noticeable that the type of soil beneath the raft affects significantly the behavior of piled rafts. Comparing with the pile and raft load share in Sacomreal - Hung Vuong project, we can see obviously that the relative percentage of total load carried by piles and raft rises considerably in Ly Chinh Thang project which placed in medium sand. Therefore, piles and raft load share is the main distinctive characteristic that diversifies this type of foundation from other type of piled foundations' design [23].
From Figs. 10, 11 16, 17 it can be seen that the total applied load on piles when being calculated by Safe is always greater than the load calculated by Plaxis 3D Foundation. Distribution force applied on each pile when being calculated by Plaxis and Safe are different because Safe does not consider the influence of the ground around the raft foundation. On the other hand, in Plaxis, special types of elements like plate elements are used to model structural behavior of the piled raft foundation. Plate elements are the 6-node triangles with six degrees of freedom per node (three translational and three rotational). In this study, embedded piles, which are modeled like beam elements are used for the model of piles. This usage offers two main benefits. First, the interaction with the continuum as the skin resistance and the foot resistance is considered. Second, the embedded piles can be placed in any direction within the subsoil without any alteration of the mesh. This is achieved by crossing through a 10-node tetrahedral soil element while creating virtual nodes. Although embedded piles do not have a "real" volume and a "real" interface, they have a virtual elastic zone which is created by assigning an equivalent pile diameter within the material data set of the embedded piles. This virtual elastic zone sets aside the plastic behavior of the soil within the zone and approaches to the actual volume pile behavior [22]. Moreover, because of the "virtual" volume and interface, it is impossible to evaluate the effect of strength reduction factor (Rinter). Rinter is taken as rigid (1.0) with the assumption that the interface does not affect to the strength in the surrounding soil [23].

Moreover, in Plaxis 3D Foundation, the model has to be divided into elements which compose the "finite element mesh". As a result, the settlements and stresses are expected to have major fluctuations by changing the mesh as very coarseness, coarseness, medium, fine or very fine.

\section{CONCLUSIONS}

The contribution of raft to the total bearing capacity of piled raft foundation in the core wall foundation of high-rise buildings depends on the geotechnical characteristics of the soil beneath the raft. Indeed, while in soft soil, the piles bear mostly the load transmitted to the foundation (approximately $96 \%$ ), this percentage only reaches around 90\% when the construction is located on hard soil. It means that the role of the raft in sharing load increases considerably (about 6\%) in case of the high-rise building is located on hard soil.

If the core wall foundation of a high-rise building is placed on a hard soil, the load-bearing capacity of the ground surrounding the pile and the raft should be taken into account to choose the optimal design plan for the core foundation.

When choosing the calculation method of core wall foundations for geotechnical problems especially for high-rise buildings, it is necessary to pay attention to the actual behavior of the structure and the interaction with the surrounding ground to have the most suitable method. 


\section{REFERENCES}

1. Baziar, M. H., Ghorbani, A. and Katzenbach, R. (2009). Small-Scale Model Test and Three-Dimensional Analysis of Pile-Raft Foundation on Medium-Dense Sand. International Journal of Civil Engineering, Iran University of Science and Technology Press, Vol. 7, No. 3.

2. Hemsley, J. A. (2000). Design applications of raft foundations. Thomas Telford Ltd, London.

3. Randolph M.F. (1994). Design method for pile groups and pile rafts. Proc. 13th Int. Conf. Soil Mechanic, Foundation Engineering, New Delhi, 5, pp. 61-82.

4. Beckett D. (2000). Design Application of Raft Foundation. 1st edition, Thomas Telfort books, London, page 1-38.

5. Bowels J.E. (1996). Foundation Analysis and Design, Mcgraw Hill International Edititons.

6. Poulos, H.G. (1991). Foundation economy via piledraft systems. Proc. Piletalk International, Kualar Lumpur, Malaysia, pp. 97-106.

7. Poulos, H.G. (1994). An approximate numerical analysis of pile-raft interaction. Int. J. Num. Anal. Meth. Geomech, 8, 2, pp. 73-92.

8. Russo G., Viggiani C. (1997). Some aspects of numerical analysis of piled rafts. Proc. 14th Int. Conf. Soil Mechanic, Foundation Engineering, Hamburg, 2, pp. 1125-1128.

9. Viggiani C. (1998). Pile groups and piled raft beaviour. Proc. 3rd Int. Geotech, Sem. On Deep Foundation on Bored and Auger piles, Ghent, Oct. pp. 77-91.

10. Hain, S.J, Lee I.K. (1978). he analysis of flexible raftpile systems. Geotechnique 28, 1, pp. 65-83.

11. Desai, C. S., Johnson, L. D., and Hargett, C. M. (1974). Analysis of pile supported gravity lock. J. Geotech. Engng, ASCE, 100(9), 1009-1029.

12. Hewitt, P. and Gue, S.S. (1994). Piled Raft Foundation in a Weathered Sedimentary Formation, Kuala Lumpur, Malaysia. Proc. Geotropika '94, Malacca, Malaysia, pp. 1-11.

13. Maharaj D. K., Gandhi, S. R. (2004). Non-linear finite element analysis of piled-raft foundations. Geotechnical Engineering, Volume 157 Issue 3, pp. 107-113.

14. Seo, Y. K., Lee, H. J., Kim, T. H. (2006). Numerical Analysis of Piled-Raft Foundation Considering Sand Cushion Effects. Proceedings of the 16th International Offshore and Polar Engineering Conference, San Francisco, California, USA, May 28-June 2, 2006, pp. 608-613.
15. Hassen, G and de Buhan, P. (2005). Finite Element Elastoplastic of a Piled Raft Foundation Based on the Use of a Multiphase Model. Proceedings of the 8th International Conference on Computational Plasticity, COMPLAS VIII, Barcelona, Spain.

16. Katzenbach, R. et al. (1938). Group-efficiency of large pile roup in rock. Proc. 3rd Int. Geotech, Sem. On Deep Foundation on Bored and Auger piles, Ghent, Oct. pp. 223-229.

17. Katzenbach, R. et al. (1998). Piled raft foundation: interaction between piles and raft. Proc. Int. Conf. on Soil-Structure in Urban Civil Engineering, pp. 279-296.

18. Lisa J. Novak et al. (2012). Analysis of Pile-Raft Foundations with 3D Finite-Element Method. Structures Congress.

19. Noh, E. Y. et al. (2008). Finite Element Modeling for Piled-Raft in Sand. Proceedings of the Eleventh East AsiaPacific Conference on Structural, Engineering \& Construction (EASEC-11), "Building a Sustainable Environment", November 19-21, Taipei, Taiwan.

20. Anup Sinha, A. M. Hanna. (2017). 3D Numerical Model for Piled Raft Foundation. International Journal of Geomechanics, Volume 17, Issue 2.9Katzenbach. (2000). Piled raft foundation projects in Germany. Design application of raft foundations, pp. 323-393.

21. Shweta Shrestha, Nadarajah Ravichandran. (2019). $3 \mathrm{D}$ nonlinear finite element analysis of piled-raft foundation for tall wind turbines and its comparison with analytical model. Journal of GeoEngineering, Vol. 14, No. 4, pp. 259-276.

22. Brinkgreve, R.B.J., Swolfs, W.M. (2007). PLAXIS 3D Foundation, Finite element code for soil and rock analyses, Users Manual, Plaxis BV, Delft, The Netherlands.

23. Nurullah Sönmez. (2013). A study on design of piled raft foundation systems. Master thesis, Middle East Technical University.

24. https://www.csiamerica.com/
Paper submitted: 06.01.2021.

Paper accepted: 17.04.2021.

This is an open access article distributed under the CC BY 4.0 terms and conditions. 